\title{
Pengaruh suplementasi zink terhadap parameter hematologi atlet sepatu roda setelah latihan endurance
}

The effect of zinc supplementation on hematologic parameters of a skate athlete after endurance exercise

\author{
Mirza Hapsari Sakti Titis Penggalih', Mustika Cahya Nirmala Dewinta², Choiri Khumaidah Fikriyah ${ }^{2}$, \\ Noni Kustia ${ }^{2}$, Assyifatu Rahmah Zada ${ }^{2}$, Zaenal Muttaqien Sofro ${ }^{3}$, Bernadette Josephine Istiti Kandarina ${ }^{4}$ \\ ${ }^{1}$ Departemen Gizi Kesehatan, Fakultas Kedokteran, Kesehatan Masyarakat, dan Keperawatan Universitas Gadjah Mada \\ ${ }^{2}$ Mahasiswa Departemen Gizi Kesehatan, Fakultas Kedokteran, Kesehatan Masyarakat, dan Keperawatan Universitas Gadjah Mada \\ ${ }_{3}^{3}$ Departemen Fisiologi, Fakultas Kedokteran, Kesehatan Masyarakat, dan Keperawatan Universitas Gadjah Mada \\ ${ }^{4}$ Program Studi Magister Ilmu Kesehatan Masyarakat, Fakultas Kedokteran, Kesehatan Masyarakat, dan Keperawatan Universitas Gadjah Mada
}

\begin{abstract}
Background: In sports such as roller skates, endurance can lead to increased inflammation and muscle cell damage, free radical formation, and zinc excretion from sweat and urine that affect the increased redistribution of zinc from blood to tissue. This mechanism causes a decrease in blood zinc levels, erythrocyte numbers and hemoglobin concentrations, increased leukocyte counts and the body's oxidative stress parameters that have an impact on the athlete's performance decline. Zinc supplementation may be given to maintain the athlete's hematologic parameters during endurance exercise. Objective: To examine the effect of zinc supplementation on serum zinc level, hemoglobin concentration, erythrocyte and leukocyte counts, and blood MDA level of skate athletes after endurance exercise. Method: This study was an experimental clinical trial using pre and post-test designs on 8 athletes incorporated in the pre-PON DIY wheels team. The study was conducted in two periods, one week of endurance exercise without zinc supplementation and one week of endurance exercise with $30 \mathrm{mg} / \mathrm{d}$ of zinc supplementation. Blood sampling was performed on the seventh day of each period, before and after endurance training. Results: There was a decrease in erythrocytes and hemoglobin concentration, and a significant increase in leukocyte count after endurance training in both periods ( $p<0.05)$, but no significant difference in serum zinc levels and MDA levels after endurance training in both periods ( $p>0.05)$. Although there were no significant differences in all athlete hematologic parameters between two treatments ( $p>0.05)$, there was an improvement in serum zinc levels, hemoglobin concentrations, erythrocyte, and leukocyte counts. Conclusion: Zinc supplementation $30 \mathrm{mg} /$ day for one week did not have a significant effect on the athlete's hematology parameters after endurance exercise.
\end{abstract}

KEY WORDS: endurance training; hematological parameters; zinc supplementation

\section{ABSTRAK}

Latar belakang: Pada olahraga seperti sepatu roda, endurance dapat menyebabkan peningkatan inflamasi dan kerusakan sel otot, pembentukan radikal bebas, dan ekskresi zink dari keringat serta urin yang mempengaruhi peningkatan redistribusi zink dari darah ke jaringan. Mekanisme tersebut menyebabkan penurunan kadar zink darah, angka eritrosit, dan konsentrasi hemoglobin, meningkatkan angka leukosit serta parameter stres oksidatif tubuh yang berdampak pada penurunan performa atlet. Suplementasi zink dapat diberikan untuk menjaga parameter hematologi atlet selama latihan endurance. Tujuan: Penelitian ini mengkaji pengaruh suplementasi zink terhadap kadar zink serum, angka eritrosit dan leukosit, konsentrasi hemoglobin, dan kadar malondialdehid (MDA) atlet sepatu roda setelah latihan endurance. Metode: Penelitian ini merupakan uji klinis eksperimental dengan menggunakan rancangan pre dan post-test terhadap 8 atlet yang tergabung dalam tim sepatu roda pra-PON DIY 2015. Penelitian dilakukan dalam dua periode, yaitu periode latihan endurance tanpa suplementasi zink dan periode latihan endurance dengan suplementasi zink sebanyak $30 \mathrm{mg}$ /hari. Seluruh responden menjalani dua periode tersebut. Pengambilan sampel darah dilakukan di hari ketujuh pada masing-masing periode, sebelum dan setelah latihan endurance. Hasil: Terjadi penurunan angka eritrosit dan konsentrasi hemoglobin serta peningkatan angka leukosit yang signifikan setelah latihan endurance pada kedua periode $(\mathrm{p}<0,05)$, tetapi tidak terdapat beda signifikan pada kadar serum zink dan kadar MDA setelah latihan endurance pada kedua periode (p>0,05). Meskipun

Korespondensi: Mirza Hapsari Sakti Titis Penggalih, Departemen Gizi Kesehatan, Fakultas Kedokteran, Kesehatan Masyarakat, dan Keperawatan Universitas Gadjah Mada, Jl. Farmako Sekip Utara, Yogyakarta 55281, Telp/Fax. 0274-547775, e-mail: mirza.hapsari@ugm.ac.id 
tidak terdapat perbedaan bermakna pada semua variabel hematologi atlet antara dua perlakuan ( $\mathrm{p}>0,05)$, terdapat perbaikan level zink serum, konsentrasi hemoglobin, serta angka eritrosit dan leukosit. Simpulan: Suplementasi zink $30 \mathrm{mg} / \mathrm{hari}$ selama satu minggu tidak memberikan pengaruh signifikan terhadap parameter hematologi atlet setelah latihan endurance.

KATA KUNCI: latihan endurance; parameter hematologi; suplementasi zink

\section{PENDAHULUAN}

Olahraga endurance seperti sepatu roda adalah tipe olahraga yang memiliki tingkat stres oksidatif tinggi, meningkatkan kerusakan otot dan jaringan, serta memicu terjadinya inflamasi yang berdampak pada penurunan imunitas tubuh (1). Pengaruh olahraga endurance terhadap fungsi sistem imun juga terjadi lewat perubahan aktivitas neuroendokrin, yaitu pelepasan hormon stres seperti katekolamin dan kortikosteroid yang memicu penurunan fungsi sistem imun (2). Salah satu komponen yang berperan dalam homeostasis sistem imun adalah leukosit. Jumlah leukosit yang tinggi dapat menjadi tanda bahwa kemungkinan atlet belum pulih benar dari sesi latihan sebelumnya atau juga menandakan bahwa atlet mengalami infeksi (3).

Status zink atlet berpengaruh terhadap performanya. Penelitian terdahulu menunjukkan bahwa atlet sepakbola yang memiliki kadar serum zink rendah (hipozincemia) mengalami penurunan performa dan peningkatan viskositas darah yang disebabkan oleh peningkatan fragilitas eritrosit (4). Keluarnya zink dari keringat dan peningkatan zinc uptake dari darah ke otot akibat adanya kerusakan atau inflamasi sel otot. Rendahnya jumlah zink mengurangi peak power output dan menurunkan lactate threshold sehingga konsentrasi serum zink yang kurang dapat menjadi indikator melemahnya fungsi fisiologis terkait ketidakcukupan asupan zink dan/atau kehilangan zink dalam jumlah yang besar $(5,6)$.

Selain itu, selama latihan endurance akan terjadi peningkatan aktivitas radikal bebas. Radikal bebas yang terbentuk oleh tubuh akan menyerang asam lemak tidak jenuh ganda pada membran sel yang disebut sebagai reaksi peroksidasi lemak. Peroksidasi lemak, terutama pada asam lemak arakhidonat, asam lemak eikosapentaenoat, dan asam lemak dokosaheksanoat akan menghasilkan senyawa malondialdehid (MDA) yang merupakan salah satu penanda tidak langsung terjadinya stres oksidatif (7).

Aktivitas radikal bebas yang meningkat selama latihan endurance juga dapat merusak sel darah merah (eritrosit), yang berpengaruh juga pada penurunan jumlah hemoglobin yang memiliki peran sebagai pengangkut oksigen ke jarigan sel, termasuk sistem kardiovaskular. Terhambatnya fungsi sistem kardiovaskular akibat menurunnya transport oksigen tersebut berdampak negatif pada ketahanan aerobik atlet sehingga mengganggu performa atlet secara keselutuhan $(7,8)$. Penurunan jumlah eritrosit dan kadar hemoglobin pada atlet endurance juga terjadi melalui mekanisme peningkatan cardiac output untuk memenuhi aktivitas otot, jantung, paru-paru, dan otak selama aktivitas fisik. Keadaan ini mengakibatkan terjadinya iskemik pada mukosa usus dan memicu hilangnya sel darah merah dari usus. Penurunan jumah sel darah merah tersebut diiringi dengan penurunan jumlah hemoglobin (9).

Berkaitan dengan imunitas, salah satu zat gizi yang berperan dalam fungsi imun adalah zink. Zink berperan sebagai antioksidan yang melawan peningkatan aktivitas radikal bebas akibat latihan fisik. Peran zink sebagai antioksidan terjadi melalui beberapa mekanisme, diantaranya berikatan dengan protein di membran sel untuk menghambat produksi radikal bebas hidrogen peroksida; memicu perkembangan dan aktivitas sistem imun non-spesifik termediasi sel seperti neutrofil dan sel natural killer (NK); meningkatkan perkembangan, aktivasi, dan produksi sel T-helper dan limfosit B; dan memicu aktivitas metallothionein (MT), sebuah senyawa protein kaya sistein yang merupakan agen scavenger ion hidrogen peroksida (10).

Menanggapi adanya hubungan antara latihan endurance, status zink serta parameter hematologi lainnya terhadap performa, beberapa penelitian telah dilakukan untuk mengkaji pengaruh pemberian suplementasi zink pada performa atlet. Penelitian terdahulu menyebutkan bahwa suplementasi zink berpengaruh pada peningkatan aktivitas antioksidan tubuh melalui mekanisme penekanan peroksidasi lipid dan aktivasi sistem antioksidan tubuh (11). Suplementasi zink $22 \mathrm{mg} /$ hari terhadap atlet sepakbola laki-laki pada studi sebelumnya (12) 
memberikan hasil adanya peningkatan kadar plasma zink dan Fe eritrosit, penurunan kadar zink urin, serta penurunan fragilitas eritrosit, dan tidak memberikan efek samping penurunan kadar plasma $\mathrm{Fe}$ dan $\mathrm{Cu}$. Selain itu, suplementasi zink sebanyak $2,5 \mathrm{mg} / \mathrm{kgBB} /$ hari pada atlet tinju laki-laki menghasilkan adanya perbaikan jumlah eritrosit, leukosit, hemoglobin, dan hematokrit dibandingkan dengan kelompok tanpa suplementasi (13).

Meskipun demikian, pengaruh pemberian suplementasi zink terhadap profil hematologi atlet setelah latihan endurance masih menjadi hal yang belum dapat dijelaskan secara pasti. Sementara itu, atlet yang melakukan olahraga endurance berisiko mengalami perubahan status zink yang lebih tinggi daripada olahraga lainnya. Penelitian pada atlet balap sepeda terlatih menyebutkan bahwa mereka mengalami 50-60\% peningkatan ekkresi zink melalui urin bila dibandingkan dengan sebelum latihan (6). Penurunan kadar zink setelah latihan endurance yang berkaitan dengan parameter hematologi dipicu oleh peningkaran distribusi zink ke jaringan sel yang rusak akibat aktivitas radikal bebas yang meningkat selama latihan (5). Mengingat besarnya pengaruh latihan endurance terhadap status zink dan parameter hematologi lainnya, maka diperlukan kajian lebih lanjut mengenai pengaruh pemberian suplementasi zink terhadap parameter hematologi yang spesifik pada atlet dengan tipe olahraga endurance. Dengan demikian, tujuan penelitian ini adalah mengkaji pengaruh suplementasi zink terhadap kadar zink serum, angka eritrosit dan leukosit, konsentrasi hemoglobin, dan kadar malondialdehid (MDA) pada atlet sepatu roda setelah latihan endurance.

\section{BAHAN DAN METODE}

Jenis penelitian ini adalah uji klinis eksperimental dengan menggunakan rancangan pre dan post-test. Penelitian dirancang untuk membandingkan pengaruh antara dua perlakuan atau intervensi yang berbeda, yaitu latihan endurance tanpa suplementasi zink dan latihan endurance dengan suplementasi zink. Penelitian dilakukan pada Bulan Juli - September 2015 di Asrama Dharma Putera Yogyakarta. Subjek penelitian adalah atlet sepatu roda sebanyak 8 orang yang tergabung dalam tim sepatu roda pra-Pekan Olahraga Nasional (PON) Daerah Istimewa Yogyakarta (DIY) 2015 yang telah memenuhi kriteria inklusi dan eksklusi. Besar subjek dihitung menggunakan rumus perhitungan sampel untuk penelitian eksperimental (14) dengan besar sampel minimal sebanyak 5 orang yang dipilih secara consecutive sampling. Kriteria inklusi yaitu subjek dalam kondisi sehat dan bersedia menandatangani informed consent. Kriteria eksklusi subjek adalah cedera, patah tulang, atau sedang dalam masa perawatan sehingga tidak dapat mengikuti jalannya penelitian.

Pada tahap pelaksanaan penelitian, seluruh subjek mendapatkan pengaturan diet dari ahli gizi sesuai dengan kebutuhan gizi masing-masing individu. Perhitungan kebutuhan gizi (energi, protein, lemak, karbohidrat) untuk atlet dalam studi ini dihitung berdasarkan berat badan, tinggi badan, usia, aktivitas fisik, serta tambahan energi untuk latihan setiap hari. Perhitungan tersebut untuk mencukupi 100\% kebutuhan energi dan zat gizi sehari-hari. Seluruh subjek menjalani jenis latihan yang sama, pada waktu dan tempat yang sama pula. Subjek mendapatkan kedua macam perlakuan, yaitu perlakuan tanpa suplementasi pada periode pertama selama satu minggu dan perlakuan dengan suplementasi zink pada periode kedua selama satu minggu berikutnya. Pada setiap periode, subjek menjalani latihan endurance rutin setiap hari Senin hingga Jumat, pada pagi dan sore hari. Subjek mendapatkan waktu libur di hari Sabtu dan menjalani latihan endurance berupa bersepeda atau bersepatu roda jarak jauh pada hari Minggu. Penelitian terdahulu yang memberikan $20 \mathrm{mg}$ zink/hari selama satu minggu pada atlet laki-laki memberikan hasil adanya perbaikan terhadap deformabilitas eritrosit, mencegah peningkatan viskositas darah akibat stres saat latihan fisik, dan meningkatkan kapasitas endurance atlet (4). Suplemen zink yang diberikan pada penelitian ini adalah Zinc Sulphate Monohydrate dalam bentuk sirup sebanyak $7 \mathrm{~mL} /$ hari (setara dengan $30 \mathrm{mg}$ zink/hari), diberikan pada pagi dan sore hari sebelum latihan sebanyak $3,5 \mathrm{~mL}$ (15 mg zink) setiap pemberian.

Pengambilan sampel darah dilakukan oleh petugas laboratorium profesional pada hari Minggu, pagi hari sebelum latihan dan sore hari setelah latihan. Pengujian serum zink dilakukan di laboratorium dengan metode 
Atomic Absorption Spectroscopy (AAS) sedangkan pengujian angka eritrosit, angka leukosit, dan konsentrasi hemoglobin dilakukan menggunakan alat Hematology Analyzer Sysmex XT 2000i. Lebih lanjut, pengujian kadar MDA menggunakan metode Thiobarbituric Acid Reactive Substances (TBARS).

Analisis bivariat menggunakan independent t-test untuk mengetahui ada tidaknya perbedaan rerata nilai setiap variabel antara dua perlakuan. Sementara untuk mengetahui ada atau tidaknya perbedaan rerata nilai setiap variabel sebelum dan sesudah pemberian suplemen zink, digunakan uji statistik paired t-test. Derajat signifikansi ditetapkan dengan nilai $\mathrm{p}<0,05$. Penelitian ini telah memperoleh ethical approval dengan nomor KE/FK/909/EC dari Komisi Etik Fakultas Kedokteran Universitas Gadjah Mada.

Tabel 1. Rerata pemenuhan energi dan zat gizi subjek penelitian $(\mathbf{n}=8)$

\begin{tabular}{lc}
\hline Energi dan zat gizi/hari & Rerata \pm SD \\
\hline Energi $(\mathrm{kcal})$ & $4513,12 \pm 769,19$ \\
Protein $(\mathrm{g})$ & $169,25 \pm 28,8$ \\
Lemak $(\mathrm{g})$ & $100,37 \pm 16,96$ \\
Karbohidrat $(\mathrm{g})$ & $733,37 \pm 125,01$ \\
Zink dari makanan $(\mathrm{mg})$ & $14,34 \pm 2,94$ \\
\hline
\end{tabular}

\section{HASIL}

Subjek yang berpartisipasi sebanyak 5 orang lakilaki dan 3 orang perempuan, dengan rerata berat badan $48,24 \mathrm{~kg}$ dan rerata tinggi badan $160,16 \mathrm{~cm}$. Usia termuda subjek adalah 13 tahun dan usia tertua 34 tahun. Selama proses penelitian, semua subjek menerima pengaturan diet dari ahli gizi yang disesuaikan dengan kebutuhan energi masing-masing individu. Kajian terhadap rerata pemenuhan energi dan zat gizi berdasarkan standar diet yang diterima atlet ditampilkan dalam Tabel 1.

Mengacu pada rekomendasi kebutuhan zink berdasarkan Angka Kecukupan Gizi (AKG) tahun 2013 pada kelompok umur 10-18 tahun, yaitu 14-18 mg/hari untuk laki-laki dan 13-16 mg/hari untuk perempuan (15), maka pemenuhan zink dari diet yang diberikan kepada subjek (14,34 mg/hari) telah memenuhi kecukupan.

Berdasarkan hasil analisis deskriptif, diketahui bahwa pada kedua periode, yaitu periode tanpa suplementasi zink dan dengan suplementasi zink, terjadi penurunan kadar serum zink, angka eritrosit, konsentrasi hemoglobin, dan kadar MDA setelah latihan endurance. Sementara itu, pada kedua periode juga terjadi peningkatan angka leukosit setelah latihan endurance. Tabel 2 menunjukkan bahwa pada kedua

Tabel 2. Nilai parameter hematologi atlet sebelum dan setelah latihan endurance

\begin{tabular}{llccccc}
\hline \multirow{2}{*}{ Periode } & & \multicolumn{5}{c}{ Rerata \pm SD } \\
\cline { 3 - 7 } & & $\begin{array}{c}\text { Serum zink } \\
(\boldsymbol{\mu g} / \mathbf{d L})\end{array}$ & $\begin{array}{c}\text { Angka eritrosit } \\
(\mathbf{s e l} / \boldsymbol{\mu L})\end{array}$ & $\begin{array}{c}\text { Angka leukosit } \\
(\mathbf{s e l} / \boldsymbol{\mu L} \mathbf{L}\end{array}$ & $\begin{array}{c}\text { Hemoglobin } \\
(\mathbf{g} / \mathbf{d L})\end{array}$ & $\begin{array}{c}\text { Kadar MDA } \\
(\mathbf{n m o l} / \mathbf{m L})\end{array}$ \\
\hline \multirow{3}{*}{ Tanpa suplementasi zink } & Pre & $77,58 \pm 0,64$ & $5,141 \pm 0,384$ & $7.930 \pm 1.045$ & $14,263 \pm 0,754$ & $3,78 \pm 0,57$ \\
& Post & $76,97 \pm 0,66$ & $4,790 \pm 0,460$ & $8.460 \pm 830$ & $13,450 \pm 0,812$ & $3,06 \pm 0,63$ \\
& Nilai $\mathrm{p}$ & 0,201 & $0,007 *$ & $0,048^{*}$ & $0,000^{*}$ & 0,066 \\
Suplementasi zink & Pre & $78,02 \pm 0,54$ & $5,158 \pm 0,423$ & $7.910 \pm 1.982$ & $14,388 \pm 0,729$ & $4,25 \pm 0,42$ \\
& Post & $77,41 \pm 0,94$ & $4,885 \pm 0,384$ & $9.910 \pm 2.210$ & $13,575 \pm 0,754$ & $3,57 \pm 0,88$ \\
& Nilai $\mathrm{p}$ & 0,171 & $0,038^{*}$ & $0,000^{*}$ & $0,000^{*}$ & 0,057 \\
\hline
\end{tabular}

*signifikan $(\mathrm{p}<0,05)$

Tabel 3. Selisih nilai parameter hematologi atlet sebelum dan setelah latihan

\begin{tabular}{lccccc}
\hline \multirow{2}{*}{ Periode } & \multicolumn{5}{c}{ Rerata \pm SD } \\
\cline { 2 - 6 } & $\begin{array}{c}\text { Serum zink } \\
(\boldsymbol{\mu g} / \mathbf{d L})\end{array}$ & $\begin{array}{c}\text { Angka eritrosit } \\
(\mathbf{s e l} / \boldsymbol{\mu L})\end{array}$ & $\begin{array}{c}\text { Angka leukosit } \\
(\mathbf{s e l} / \boldsymbol{\mu L})\end{array}$ & $\begin{array}{c}\text { Hemoglobin }(\mathbf{g} / \\
\mathbf{d L})\end{array}$ & $\begin{array}{c}\text { Kadar MDA } \\
(\mathbf{n m o l} / \mathbf{m L})\end{array}$ \\
\hline Tanpa suplementasi zink & $-0,61 \pm 1,22$ & $-0,3513 \pm 0,267$ & $532,50 \pm 628,19$ & $-0,8125 \pm 0,340$ & $0,72 \pm 0,93$ \\
Suplementasi zink & $-0,62 \pm 1,14$ & $-0,2725 \pm 0,302$ & $2.000 \pm 1.893,93$ & $-0,8125 \pm 0,331$ & $0,69 \pm 0,85$ \\
Nilai p & 0,990 & 0,590 & 0,069 & 1,000 & 0,695 \\
\hline
\end{tabular}

*signifikan $(\mathrm{p}<0,05)$ 
periode, perubahan kadar serum zink dan kadar MDA sebelum dan setelah latihan tidak memiliki perbedaan signifikan $(p>0,05)$ sedangkan perubahan angka eritrosit, hemoglobin, dan leukosit menunjukkan perbedaan signifikan $(\mathrm{p}<0,05)$. Berdasarkan hasil tersebut, latihan endurance yang dijalani subjek belum memberikan pengaruh secara signifikan terhadap perubahan kadar serum zink dan kadar MDA atlet.

Pengaruh pemberian suplementasi zink selama satu minggu terhadap perubahan parameter hematologi atlet setelah latihan endurance dilihat dari selisih kadar serum zink setelah-sebelum latihan pada kedua kondisi. Perbandingan selisih keduanya ditampilkan dalam Tabel 3, yang secara deskriptif menunjukkan terjadinya penurunan rerata kadar serum zink, kadar MDA, angka eritrosit dan konsentrasi hemoglobin, serta peningkatan angka leukosit setelah latihan pada kedua periode. Analisa statistik independent t-test menunjukkan bahwa tidak ada perbedaan bermakna di antara kedua periode $(p>0,05)$.

\section{BAHASAN}

Hasil pengukuran kadar serum zink menunjukkan bahwa seluruh subjek memiliki kadar serum zink yang normal, baik sebelum maupun setelah latihan, dan dalam kondisi tersuplementasi zink maupun tidak. Batas bawah atau lower cut-off kadar zink yang normal menurut International Zinc Consultant Group (IZinCG) adalah $70 \mu \mathrm{g} / \mathrm{dL}$ untuk laki-laki dan $66 \mu \mathrm{g} / \mathrm{dL}$ untuk perempuan (16). Secara deskriptif, rerata kadar serum zink, angka eritrosit, konsentrasi hemoglobin, dan kadar MDA atlet mengalami penurunan setelah latihan endurance, baik pada kondisi tanpa suplementasi zink maupun dengan suplementasi zink. Penurunan kadar serum zink setelah latihan endurance disebabkan oleh hilangnya zink melalui keringat dan urin saat latihan. Penurunan kadar zink ini juga dapat disebabkan oleh meningkatnya distribusi zink dari darah ke jaringan sel yang rusak akibat radikal bebas yang dipicu oleh peningkatan stres oksidatif karena latihan $(6,17)$. Mekanisme ini berkaitan dengan peran zink sebagai kofaktor berbagai metaloenzim, salah satunya superoxide dismutase (SOD) yang berfungsi sebagai antioksidan dalam tubuh. Pada kondisi ini, zink sebagai komponen dari enzim SOD akan didistribusikan ke jaringan yang rusak sehingga kadarnya di dalam darah menurun $(17,18)$.

Menurunnya kadar serum zink secara signifikan dan terjadi dalam jangka waktu yang lama dapat meningkatkan risiko terjadinya defisiensi zink pada atlet. Atlet yang memiliki kadar serum zink rendah akan mengalami peningkatan fragilitas eritrosit yang menyebabkan peningkatan viskositas darah dan memicu penurunan performa (4). Hal tersebut berkaitan dengan pengaruh kadar serum zink yang rendah terhadap penurunan peak power output dan menurunkan lactate threshold sehingga mengurangi kekuatan otot dan kapasitas latihan (6).

Salah satu penyebab penurunan jumlah eritrosit setelah latihan adalah hemolisis. Ada dua hal penyebab utama hemolisis yang terjadi setelah latihan yaitu stres oksidatif dan stres mekanik. Stres oksidatif dapat mengubah homeostasis ionik dan menyebabkan dehidrasi seluler. Perubahan tersebut akan menurunkan deformabilitas eritrosit sehingga eritrosit mudah rusak saat melewati mikrosirkulasi yang sempit (19). Penyebab kedua dari hemolisis setelah latihan adalah stres mekanik. Eritrosit pecah akibat tekanan yang ditimbulkan oleh benturan telapak kaki yang keras pada permukaan tanah saat latihan. Hal tersebut diperparah dengan rusaknya membran eritrosit akibat stres oksidatif yang menurunkan deformabilitas eritrosit dan membuatnya semakin mudah pecah (20). Kemungkinan lain yang menjadi penyebab penurunan jumlah eritrosit setelah latihan endurance adalah hilangnya darah dari saluran gastrointestinal dan mikroskopik hematuria. Pada saat latihan endurance, cardiac output akan meningkat dan diutamakan untuk memenuhi kebutuhan metabolik otot, jantung, paru-paru, dan otak. Hal ini menyebabkan aliran darah ke sistem pencernaan menjadi menurun hingga $80 \%$ pada $\mathrm{VO}_{2 \max } 70 \%$. Penurunan tersebut menyebabkan mukosa intestinum mengalami iskemik sehingga permeabilitasnya meningkat dan memicu hilangnya darah dari intestinum (21). Penurunan eritrosit akibat latihan endurance pada penelitian ini dianggap masih aman karena jumlah eritrosit setelah latihan tetap dalam range normal. Penelitian ini memiliki keterbatas data yang dapat digunakan untuk mengonfirmasi adanya hemolisis intravaskuler, kehilangan darah melalui saluran 
gastrointestinal, dan juga peningkatan plasma. Penurunan angka eritrosit ini pula yang memicu turunnya konsentrasi hemoglobin.

Lebih lanjut, pada kondisi latihan fisik yang berat, terjadi peningkatan aktivitas radikal bebas. Radikal bebas yang terbentuk oleh tubuh akan menyerang asam lemak tidak jenuh ganda pada membran sel yang disebut sebagai reaksi peroksidasi lemak. Peroksidasi lemak, terutama pada asam lemak rakhidonat, asam lemak eikosapentaenoat, dan asam lemak dokosaheksanoat akan menghasilkan senyawa MDA. Dengan demikian, kadar MDA pada keadaan stres oksidatif akan meningkat secara signifikan dan jika keadaan stres oksidatif teratasi kadarnya akan kembali menurun $(22,23)$. Terjadinya penurunan kadar MDA setelah latihan pada penelitian ini kemungkinan karena adanya sistem pertahanan antioksidan tubuh sebagai respon kronis terhadap aktivitas fisik yang teratur. Respon kronis $\beta$ tersebut dilaporkan mulai terjadi setelah menjalani aktivitas fisik teratur selama 8 sampai 12 minggu. Secara kronis, aktivitas fisik secara teratur dapat meningkatkan kapasitas antioksidan endogen dan menurunkan stres oksidatif. Antioksidan endogen meliputi enzim superoksid dismutase (SOD), katalase (CAT), glutation peroksidase (GPx), dan glutation (GSH) (19,22).

Sementara itu, jumlah leukosit yang meningkat menunjukkan bahwa tubuh sedang melawan infeksi dan menjaga homeostasis dalam keadaan normal yang merupakan suatu upaya tubuh untuk menghilangkan stres fisik yang mempengaruhi sistem imun (3). Peningkatan jumlah leukosit akibat latihan endurance dapat terjadi karena mediasi kortisol, demarginasi, neuron transmitter, dan peptida atau purine chemical transmitters. Selanjutnya, peningkatan jumlah leukosit juga dapat disebabkan oleh terjadi peningkatan pelepasan leukosit dari tempat penyimpanan leukosit di sumsum tulang, menurunnya ekstravasasi leukosit dari pembuluh darah ke dalam jaringan, dan peningkatan sel prekursor dalam sumsum tulang. Penyebab lain yang dapat meningkatkan jumlah leukosit setelah aktivitas fisik adalah adanya radikal bebas. Aktivitas fisik yang berat dan melelahkan berakibat pada meningkatnya jumlah radikal bebas (prooksidan) sehingga terjadi ketidakseimbangan antara antioksidan dan radikal bebas yang dapat menyebabkan stres oksidatif yang kemudian dapat merangsang aktivitas sel leukosit sehingga memicu terjadinya peningkatan jumlah leukosit melebihi normal (24).

Penurunan kadar serum zink setelah latihan pada kedua perlakuan tidak signifikan secara statistik. Hal ini kemungkinan disebabkan oleh mekanisme adaptasi metabolik yang menyebabkan tubuh membentuk cadangan zink dalam darah. Hal ini diungkapkan pada penelitian terdahulu yang menjelaskan bahwa setelah enam minggu menjalani program latihan aerobik, terjadi penurunan kadar zink darah yang signifikan, tetapi kadarnya perlahan kembali ke nilai normal setelah 12 minggu (25). Subjek pada penelitian ini merupakan atlet yang telah tergabung dalam tim dan menjalani latihan rutin selama kurang lebih sembilan minggu.

Selain itu, penelitian sebelumnya mengungkapkan bahwa pengaruh jangka pendek dari latihan endurance terhadap perubahan kadar serum zink berbeda antara individu yang aktif berolahraga dan individu yang tidak aktif. Perubahan kadar serum zink pada individu yang melakukan latihan endurance dengan frekuensi tinggi cenderung tidak signifikan. Hal ini dipengaruhi oleh ketahanan aerobik (aerobic threshold) yang lebih tinggi pada individu yang rutin melakukan latihan endurance sehingga fluktuasi kadar serum zinknya lebih rendah (5).

Pada penelitian ini, pengaruh suplementasi zink terhadap parameter hematologi atlet setelah latihan endurance dinilai dari perbandingan rerata kadarnya pada kondisi tersuplementasi zink dan tanpa suplementasi zink, serta perbandingan selisih kadar setiap variabel setelahsebelum latihan endurance pada kedua kondisi tersebut. Secara deskriptif, rerata nilai parameter hematologi atlet pada periode pemberian suplemen zink mengalami perbaikan dibandingkan periode tanpa suplemen, yang ditunjukkan dengan peningkatan rerata baseline kadar serum zink, angka eritrosit, dan konsentrasi hemoglobin, serta penurunan baseline angka leukosit atlet, meskipun secara statistik tidak ada perbedaan yang bermakna di antara kedua periode tersebut ( $\mathrm{p}>0,05)$.

Pengaruh suplementasi zink terhadap parameter hematologi yang tidak signifikan dalam penelitian ini kemungkinan dipengaruhi oleh telah tercukupinya kebutuhan zink yang diperoleh dari diet. Berdasarkan kajian asupan makan subjek dalam penelitian ini, 
diketahui bahwa rerata pemenuhan zink dari standar diet subjek adalah 14,34 mg/hari. Rekomendasi kebutuhan zink berdasarkan AKG tahun 2013 pada kelompok umur 10-18 tahun adalah 14-18 mg/hari untuk laki-laki dan 13-16 mg/hari untuk perempuan. Oleh karena itu, dapat disimpulkan bahwa asupan zink dari diet atlet telah memenuhi kecukupan zink yang direkomendasikan.

Seluruh subjek pada penelitian ini menerima diet sesuai dengan perhitungan kebutuhan energi dan zat gizi masing-masing individu. Bahan makanan yang dipilih adalah bahan makanan dengan protein tinggi seperti ikan, telur, dan daging. Bahan-bahan makanan tersebut merupakan bahan makanan yang mengandung kadar zink tinggi. Penelitian sebelumnya mengungkapkan bahwa pemberian suplemen zink pada individu yang telah mencukupi kebutuhan zink dari makanan tidak memberikan perubahan signifikan terhadap status zink dan performa. Perubahan yang signifikan justru terlihat pada individu yang secara klinis dan biokimia menunjukkan bukti defisiensi zink (26).

Seorang manusia dewasa dengan berat badan 70 kg memiliki 2-3 g zink dalam tubuh yang terdistribusi di otot skeletal, tulang, otak, saluran pencernaan, hati, ginjal, paru-paru, jantung, retina, pankreas, sperma, dan rahim. Berbeda halnya dengan zat besi, zink tidak memiliki tempat penyimpanan yang spesifik di dalam tubuh sehingga asupan zink yang melebihi kebutuhan akan dieksresi oleh tubuh terutama melalui feses. Selain meningkatkan ekskresi, tubuh mengontrol jumlah zink dalam tubuh dengan mengurangi absorpsi zink (27). Berdasarkan penjelasan tersebut, maka pemberian suplementasi zink pada individu yang telah mencukupi kebutuhan zink dari diet menjadi tidak efektif.

Apabila dibandingkan selisih nilai hematologi atlet sebelum dan setelah latihan antara kondisi tanpa suplementasi dengan kondisi tersuplementasi zink, diperoleh hasil bahwa tidak terdapat perbedaan yang bermakna di antara keduanya. Hal ini menunjukkan bahwa pemberian suplementasi zink secara oral sebanyak $30 \mathrm{mg} /$ hari selama satu minggu belum efektif untuk mempengaruhi parameter hematologi atlet yang berubah setelah latihan endurance. Pemberian suplementasi zink pada atlet masih menjadi kontroversi. Beberapa peneliti menyebutkan bahwa suplementasi tidak diperlukan apabila pemenuhan zink dari makanan telah memenuhi kebutuhan. Sementara itu, belum terdapat angka kecukupan zink yang pasti untuk atlet, mengingat atlet memiliki kebutuhan energi dan zat gizi yang lebih besar. Peneliti lain menyebutkan bahwa pemberian suplementasi maupun fortifikasi zink pada produk makanan bermanfaat untuk atlet ultra-endurance seperti triathlon, long lasting high altitude climbing, dan atlet yang mengikuti kompetisi olahraga selama berhari-hari (multy-day competition) (26).

Pengaruh suplementasi zink yang tidak signifikan dalam penelitian ini juga dapat dipengaruhi oleh perbedaan jenis latihan endurance yang dilakukan oleh subjek. Jenis latihan endurance yang dilakukan seluruh subjek merupakan wewenang pelatih dan tim pra-PON DIY 2015 yang tidak dapat dikontrol oleh peneliti. Pada periode tanpa suplementasi, subjek menjalani latihan endurance berupa bersepeda jarak jauh \pm 15 $\mathrm{km}$, sementara pada periode suplementasi zink, subjek menjalani latihan berupa bersepatu roda sejauh $\pm 15 \mathrm{~km}$. Berdasarkan The Compendium of Physical Activities, energi yang dikeluarkan untuk bersepatu roda lebih besar daripada bersepeda, dengan nilai metabolic equivalent (METs) masing-masing adalah 12,5 dan 8,0 (28). Oleh karena itu, tingkat stres latihan bersepatu roda pada periode suplementasi zink lebih tinggi daripada periode tanpa suplementasi, yang mengakibatkan efek pemberian suplementasi terhadap perubahan kadar serum zink menjadi tidak signifikan.

Selain adanya kemungkinan bias dari kecukupan asupan zink dari diet dan bentuk latihan yang berbeda, hasil yang tidak signifikan pada penelitian ini juga dapat dipengaruhi oleh bias dari faktor usia. Usia termuda subjek adalah 13 tahun dan usia tertua 34 tahun. Sementara itu, nilai parameter hematologi dapat beragam pada tingkat usia yang berbeda, yaitu orang dewasa cenderung memiliki nilai yang lebih tinggi (29).

\section{SIMPULAN DAN SARAN}

Pemberian suplementasi zink sebanyak $30 \mathrm{mg} /$ hari selama satu minggu tidak memberikan pengaruh signifikan terhadap parameter hematologi atlet setelah latihan endurance, meskipun terdapat perbaikan baseline 
level pada jumlah zink serum, konsentrasi hemoglobin, serta angka eritrosit dan leukosit. Peneliti menyarankan bahwa perlu penelitian lebih lanjut mengenai perbedaan perubahan parameter hematologi pada atlet endurance yang menjalani diet seimbang dan atlet yang tidak menjalani diet seimbang untuk mengetahui perlu tidaknya pemberian suplemen zink.

Penelitian ini memiliki keterbatasan pada jumlah sampel yang relatif kecil sehingga peneliti menyarankan adanya penelitian sejenis pada populasi yang lebih besar. Selain itu, penelitian mendalam untuk mengetahui dosis dan durasi pemberian suplementasi zink yang tepat juga diperlukan dengan mempertimbangkan berbagai macam karakteristik olahraga yang dijalani atlet. Selain itu, diperlukan perbaikan pada faktor-faktor bias seperti pengaturan jenis latihan endurance yang terkontrol serta pembatasan rentang usia subjek sehingga tidak mempengaruhi efektivitas pemberian suplementasi.

\section{Pernyataan konflik kepentingan}

Penulis menyatakan tidak terdapat konflik kepentingan dengan pihak-pihak yang terkait dalam penelitian ini.

\section{RUJUKAN}

1. Calle MC, Maria LF. Effects of resistance training on inflammatory response. Nutr Res Pract. 2010;4(4):259-69. doi: 10.4162/nrp.2010.4.4.259

2. Ferrari HG, Gobatto CA, Manchado-Gobatto FB. Training load, immune system, upper respiratory symptoms and performance in well-trained cyclist throughout a competitive season. Biol Sport. 2013;30(4):289-94. doi: 10.5604/20831862.1077555

3. Gleeson M. Immune function in sport and exercise. J Appl Physiol (1985). 2007;103(2):693-9. doi: 10.1152/ japplphysiol.00008.2007

4. Khaled S, Brun JF, Cassanas G, Bardet L, Orsetti A. Effects of zinc supplementation on blood rheology during exercise. Clinical hemorheology and microcirculation. Clin Hemorheol Microcirc. 1999;20(1):1-10.

5. Chu A, Samman S. Zinc homeostasis in exercise: implications for physical performance. Vitam Miner. 2014;3:e132. doi:10.4172/vms.1000e132

6. Driskell JA, Wollinsky Ira. Sports nutrition: vitamins and trace elements. USA: CRC Press; 2006.

7. Meamarbashi Abbas, Ali Rajabi. Erythrocyte osmotic fragility test revealed protective effects of supplementation with saffron and cinnamon on the red blood cell membrane. Asian Journal of Experimental Biological Science; 2013:322-6

8. Mirbaurl H. Red blood cells in sports: effects of exercise and training on oxygen supply by red blood cells. Front Physiol. 2013;4:332. doi: 10.3389/fphys.2013.00332.

9. de Oliveira EP, Burini RC. The impact of physical exercise on the gastrointestinal tract. Curr Opin Clin Nutr Metab Care. 2009;12(5):533-8. doi: 10.1097/ MCO.0b013e32832e6776.

10. Prasad AS. Zinc is an antioxidant and anti-inflammatory agent: its role in human health. Front Nutr. 2014;1:14. doi: 10.3389/fnut.2014.00014.

11. Ozturk A, Baltaci AK, Mogulkoc R, Oztekin E, Sivrikaya A, Kul A, et al. Effects of zinc deficiency and supplementation on malondialdehyde and glutathione levels in blood and tissues of rats performing swimming exercise. Biol Trace Elem Res. 2003;94(2):157-66. doi: 10.1385/BTER:94:2:157

12. de Oliveira KJF, Donangelo CM, de Oliveira AV Jr., da Silveira CL, Koury JC. Effects of zinc supplementation on the antioxidant, copper, and iron status of physically active adolescents. Cell Biochem Funct. 2009;27(3):1626. doi: 10.1002/cbf. 1550 .

13. Polat Y. Effects of zinc supplementation on hematological parameters of high performance athletes. Afr J Pharm Pharmacol. 2011;5(12):1436-40. doi: 10.5897/AJPP11.062

14. Sastroasmoro S, Sofyan I. Dasar-dasar metodologi penelitian klinis edisi ke-4. Jakarta: CV Sagung Seto; 2011.

15. Angka Kecukupan Gizi (AKG). Tabel angka kecukupan gizi bagi bangsa Indonesia. Peraturan Menteri Kesehatan Republik Indonesia Nomor 75 Tahun 2013.

16. International Zinc Consultant Group. Assessing population zinc status with serum zinc concentration: Technical Brief 2; 2007.

17. Micheletti A, Rossi R, Ruffini S. Zinc status in athlete: relation to diet and exercise. Sports Med. 2001;31(8):55782. doi: 10.2165/00007256-200131080-00002

18. Lukaski HC. Magnesium, zinc, and chromium nutriture and physical activity. Am J Clin Nutr. 2000;72(2 Suppl):585S-93S. doi: 10.1093/ajen/72.2.585S.

19. Powers SK, Jackson MJ. Exercise-induced oxidative stress: cellular mechanism and impact on muscle force production. Physiol Rev. 2008;88(4):1243-76. doi: 10.1152/physrev.00031.2007.

20. Seet RC, Lee CY, Lim EC, Quek AM, Huang H, Halliwell B, et al. Oral zinc supplementation does not improve oxidative stress or vascular function in patients with type 2 diabetes with normal zinc levels. Atherosclerosis. 2011;219(1):231-9. doi: 10.1016/j. atherosclerosis.2011.07.097. 
21. Benardot D. Advanced sports nutrition, 2nd Edition. UK: Human Kinetics; 2012.

22. Pingitore A, Lima GP, Mastorci F, Quinones A, Lervasi G, Vassalle C. Exercise and oxidative stress: potential effects of antioxidant dietary strategies in sports. Nutrition. 2015;31(7-8):916-22. doi: 10.1016/j.nut.2015.02.005.

23. Souza TP, Oliveira PR, dan Pereira Benedito. Physical exercise and oxidative stress effect of intense physical exercise on the urinary chemiluminescence and plasmatic malondialdehyde. Rev Bras Med Esporte; 2005(11): 97-10. doi: $10.1590 / \mathrm{S} 1517-86922005000100010$

24. Cooper K. Antioxidant revolution. Tennessee: Thomas Nelson Publishers; 2000.

25. Manore MM, Halleksen JM, Merkel J, Skinner JS. Longitudinal changes in zinc status in untrained men: effects of two different 12 weeks exercise training program and zinc supplementation. J Am Diet Assoc. 1993;93(10):1165-8.

26. Lukaski HC. Zinc dalam Sports nutrition: vitamin and trace minerals; second edition. Driskell JA, Wolinsky I, editor. Boca Raton: CRC Press; 2006.

27. Nriagu J. Zinc toxicity in humans. University of Michigan: Elsevier B.V; 2007.

28. Ainsworth BE, Haskell WL, Whitt MC, Irwin ML, Swartz AM, Leon AS, et al. Compendium of physical activities: an update of activity codes and MET intensities. Med Sci Sports Exerc. 2000;32(9 Suppl):S498-504.

29. Nikolaidis MG, Protosygellou MD, Petridou A, Tsalis G, Tsigilis N, Mougios V. Hematologic and biochemical profile of juvenile and adult athletes of both sexes: implications for clinical evaluation. Int J Sports Med. 2003;24(7):506-11. doi: 10.1055/s-2003-42014. 